\title{
Treatment of Cardiac Arrhythmias with Phenytoin
}

\author{
J. D. EDDY,* M.B., M.R.C.P. ; S. P. SINGH, $\dagger$ M.B., M.R.C.P.
}

\begin{abstract}
Gummary : Phenytoin was given intravenously in 37 patients with cardiac arrhythmias-21 had acute myocardial infarction and 16 had other conditions. There was a favourable response in 18 of the 21 cases with acute myocardial infarction, with a return to sinus rhythm in six of the nine cases with supraventricular arrhythmias, and a return to sinus rhythm in 10 of the 12 cases of ventricular arrhythmias, the remaining two showing a significant reduction in the number of ventricular extrasystoles.
\end{abstract}

In the second group of 16 cases which had various causes there was a satisfactory response in only six. Digitalis played no part in producing any of the arrhythmias. Phenytoin was used orally for suppressing and preventing abnormal rhythm in five patients, and three of these responded favourably. The number of patients treated orally is too small to draw any definite conclusion.

\section{Introduction}

Various agents are used for suppressing abnormal cardiac rhythm. These include quinidine, procainamide, lignocaine, and propranolol. Quinidine is not now widely used because of its reported toxic side-effects (Oram and Davies, 1964 ; Brenner et al., 1964). The other drugs are used mainly for ventricular arrhythmias. Direct current (D.C.) counter shock can cause serious ventricular arrhythmias in a digitalized patient. It would be useful to have an effective and non-toxic drug for the treatment of abnormal rhythm of both ventricular and supraventricular origin.

Phenytoin, long used as a standard therapy for epilepsy, has also been used for the treatment of arrhythmias, possibly on the rationale that the disturbances in cardiac rhythm originating in ectopic myocardial foci are analogous to seizures in the brain. Leonard (1958) recommended its use in the treatment of ventricular tachycardia. Conn (1965) reported a series of 24 cases with a variety of abnormal cardiac rhythms and found it mainly effective in arrhythmias resulting from digitalis excess. Rosen et al. (1967) also found it effective in arrhythmias that had developed in patients receiving digitalis. The purpose of the present study is to assess the action of this drug in arrhythmias unrelated to digitalis therapy.

\section{Material and Method}

Phenytoin sodium was given intravenously to 37 patients ( 30 adults and seven children). The arrhythmias were acute in onset and of less than two days' duration. In adults $250 \mathrm{mg}$. was given intravenously at a rate of about $50 \mathrm{mg}$. every minute. Children received a dose of $5 \mathrm{mg}$. $/ \mathrm{kg}$. body weight. Blood pressure was taken at frequent intervals during and after injection of the drug, and in two cases intravascular pressures were recorded from the pulmonary and systemic

\footnotetext{
- Senior Research Fellow, Dudley Road Hospital, Birmingham ; Honorary Senior Registrar in Cardiology, United Birmingham Hospitals. + Consultant Cardiologist, United Birmingham Hospitals and Regional Hospital Board; Clinical Lecturer in Medicine, Birmingham University.
}

arteries. The effect on the heart was monitored by electrocardiography.

Twenty-one patients were being treated for acute myocardial infarction in the coronary care unit. Of the remaining patients, two had rheumatic heart disease, seven congenital heart disease, one chronic ischaemic heart disease, one myocarditis, and five had no known heart lesion. In three patients abnormal rhythms had occurred during cardiac catheterization (two of these had a congenital heart lesion and one had ischaemic heart disease) and in three after cardiac surgery for a congenital heart lesion.

Phenytoin was given by mouth to five patients-four with multiple extrasystoles related to ischaemic heart disease and one with paroxysmal supraventricular tachycardia due to Ebstein's anomaly. The four adults received $100 \mathrm{mg}$. three times a day and the child $30 \mathrm{mg}$. three times a day.

Arrhythmias that responded to treatment did so within 10 minutes of starting the injection. Details of aetiology and results of treatment are summarized in Tables I and II.

\section{Results}

Arrhythmias Complicating Myocardial Infarction.-The results of treating 21 patients with acute myocardial infarction are given in Table I. There were five patients with atrial

\begin{tabular}{|c|c|c|c|c|}
\hline $\begin{array}{l}\text { Case } \\
\text { No. }\end{array}$ & Age & $\begin{array}{l}\text { Previous Antiarrhythmic } \\
\text { Treatment }\end{array}$ & Rhythm & $\begin{array}{l}\text { Response } \\
\text { to Phenytoin }\end{array}$ \\
\hline \multicolumn{5}{|c|}{ Supraventricular Arrhythmias } \\
\hline 1 & 65 & Nil & A.F. & $\begin{array}{c}\text { Transient S.R. Nodal } \\
\text { bradycardia }\end{array}$ \\
\hline $\begin{array}{r}4 \\
17 \\
25 \\
26 \\
2 \\
3 \\
20 \\
21\end{array}$ & $\begin{array}{l}55 \\
68 \\
64 \\
63 \\
57 \\
72 \\
55 \\
65\end{array}$ & $\begin{array}{l}\mathrm{Nil} \\
\mathrm{Nil} \\
\mathrm{Nil} \\
\mathrm{Nil} \\
\mathrm{Nil} \\
\mathrm{Nil} \\
\mathrm{Nil} \\
\mathrm{Nil}\end{array}$ & $\begin{array}{l}\text { A.F. } \\
\text { A.F. } \\
\text { A.F. } \\
\text { S.F. } \\
\text { S.V.T. } \\
\text { S.V.T. } \\
\text { S.V.T. } \\
\text { S.V.T. }\end{array}$ & $\begin{array}{l}\text { S.R. } \\
\text { S.R. } \\
\text { Nil } \\
\text { S.R. } \\
\text { Nil } \\
\text { S.R. } \\
\text { Nil } \\
\text { S.R. }\end{array}$ \\
\hline \multicolumn{5}{|c|}{ Ventricular Arrhythmias } \\
\hline 8 & 57 & I.V. lignocaine & V.E.S. with & S.R. \\
\hline 10 & 62 & I.V. lignocaine & $\begin{array}{l}\text { Ventricular } \\
\text { bigeminy }\end{array}$ & S.R. \\
\hline 11 & 56 & $\begin{array}{l}\text { I.V. lignocaine and I.V. } \\
\text { propranolol }\end{array}$ & V.E.S. & S.R. \\
\hline 14 & 40 & $\begin{array}{l}\text { propranolol } \\
\text { I.V. lignocaine and I.V. } \\
\text { propranolol. V.E.S. re- } \\
\text { duced to } 30-40 / \mathrm{min} \text {. } \\
\text { V.E.S. then reduced to } \\
\text { 12/min. after the latter } \\
\text { I.V. lignocaine }\end{array}$ & $\begin{array}{l}\text { Ventricular } \\
\text { bigeminy }\end{array}$ & $\begin{array}{l}\text { V.E.S. reduced from } \\
12 / \mathrm{min} \text {. to } 2-3 / \mathrm{min} \text {. }\end{array}$ \\
\hline $\begin{array}{l}15 \\
19\end{array}$ & $\begin{array}{l}53 \\
63\end{array}$ & $\begin{array}{l}\text { I.V. lignocaine } \\
\text { Nil }\end{array}$ & $\begin{array}{l}\text { V.E.S. } \\
\text { V.E.S. }\end{array}$ & $\begin{array}{l}\text { S.R. } \\
\text { V.E.S. reduced from } \\
28-30 / \mathrm{min} \text {. to } \\
6-8 / \mathrm{min} \text {. }\end{array}$ \\
\hline $\begin{array}{r}34 \\
9\end{array}$ & $\begin{array}{l}64 \\
48\end{array}$ & $\begin{array}{l}\text { I.V. lignocaine } \\
\text { I.V. lignocaine and I.V. } \\
\text { propranolol }\end{array}$ & $\begin{array}{l}\text { V.E.S. } \\
\text { V.T. }\end{array}$ & $\begin{array}{l}\text { S.R. } \\
\text { S.R. }\end{array}$ \\
\hline $\begin{array}{l}13 \\
22 \\
37\end{array}$ & $\begin{array}{l}48 \\
65 \\
57\end{array}$ & $\begin{array}{l}\text { Nil } \\
\text { Nil } \\
\text { Nil }\end{array}$ & $\begin{array}{l}\text { V.T. } \\
\text { V.T. } \\
\text { V.T. }\end{array}$ & $\begin{array}{l}\text { S.R. } \\
\text { S.R. } \\
\text { S.R. }\end{array}$ \\
\hline
\end{tabular}

Abbreviations for Tables I and II. A.F. = Atrial fibrillation. C.C. $=$ Cardiac catheterization. M.I. = Myocardial infarction. S.R. = Sinus rhythm. S.V.T. = supraventricular tachycardia. V.E.S. $=$ Ventricular extrasystoles.
cular fibrillation. A.Fl. = Atrial flutter. V.T. $=$ Ventricular tachycardia.

fibrillation, and four of these reverted to sinus rhythm (Fig. 1). Of the four cases of supraventricular tachycardia two responded to treatment with phenytoin. Ventricular arrhythmias were treated in 12 patients. Eight in this group had multiple 
ventricular extrasystoles-in six sinus rhythm was established (Fig. 2) and in two the number of ventricular extrasystoles was significantly reduced from 12 and $28-30$ /minute to $2-3$ and $6-8 /$ minute respectively. Seven of these patients had been previously treated with lignocaine. The remaining four in this group had ventricular tachycardia, and all of these reverted to sinus rhythm following intravenous phenytoin (Fig. 3). One of these had initially failed to respond to intravenous lignocaine and propranolol.

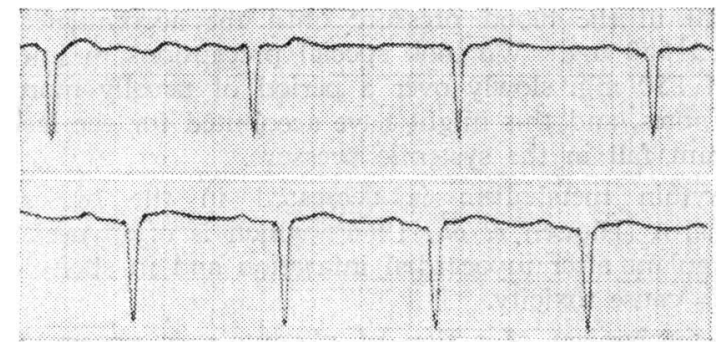

FIG. 1.-Electrocardiogram of a 55-year-old man (Case 4), showing atrial fibrillation. Bottom tracing shows sinus rhythm following $250 \mathrm{mg}$. of phenytoin sodium.

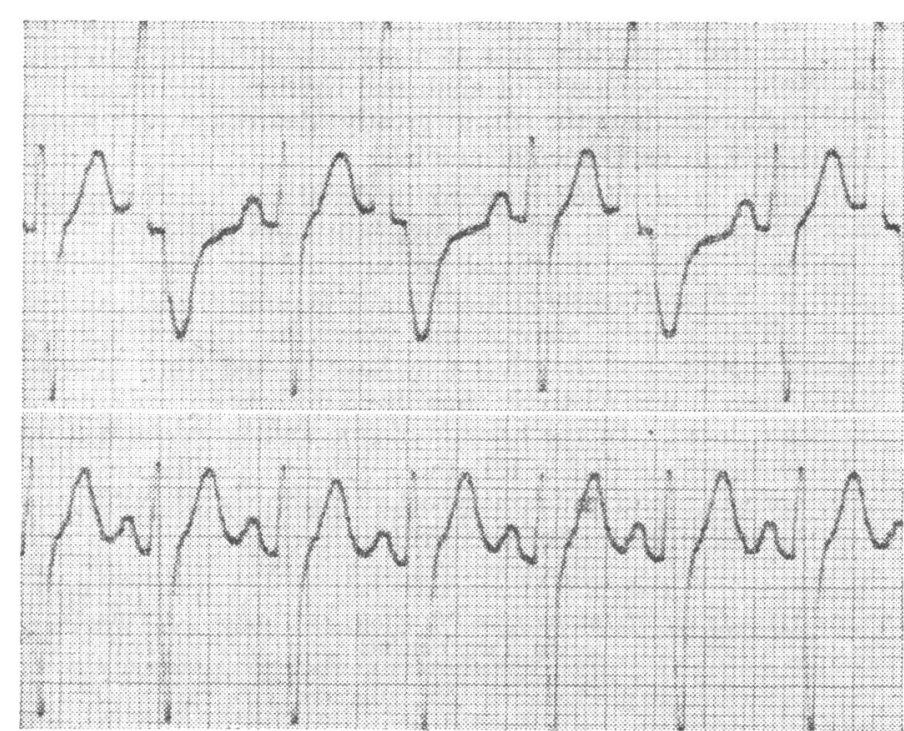

FIG. 2.-Electrocardiogram of a 40-year-old man (Case 14), showing ventricular bigeminy. Bottom tracing shows sinus rhythm following phenytoin sodium.

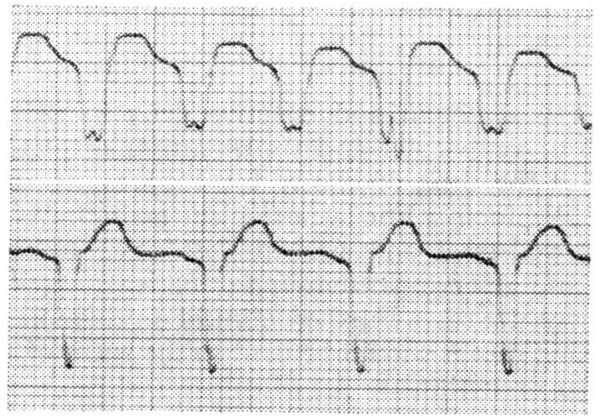

FIG. 3.-Electrocardiogram of a 48-year-old man (Case 13), showing ventricular tachycardia.
Bottom tracing shows sinus rhythm following Bottom tracing shows sinus rhythm following
the administration of intravenous phenytoin.

Arrhythmias Due to Other Causes.-A group of 16 cases had various causes (Table II), and six of them responded favourably to treatment. Sinus rhythm was restored in four of the 13 cases with supraventricular arrhythmias (Fig. 4). Of the three patients with ventricular arrhythmias there was a response to treatment in two ; the patient who failed to respond
TABLE II.-16 Cases with Various Causes

\begin{tabular}{|c|c|c|c|c|c|}
\hline $\begin{array}{l}\text { Case } \\
\text { No. }\end{array}$ & Age & Diagnosis & $\begin{array}{c}\text { Previous } \\
\text { Antiarrhythmic } \\
\text { Treatment }\end{array}$ & Rhythm & $\begin{array}{l}\text { Response } \\
\text { to } \\
\text { Phenytoin }\end{array}$ \\
\hline 6 & 54 & Rheumatic mitral & Nil & A.F. & Nil \\
\hline 23 & 65 & $\begin{array}{l}\text { 1ncompetence } \\
\text { Rheumatic mitral } \\
\text { and aortic }\end{array}$ & Nil & A.F. & Nil \\
\hline 5 & 55 & No known heart & Nil & S.V.T. & Nil \\
\hline 16 & 45 & No known heart & Nil & A.F. & Nil \\
\hline 18 & 54 & No known heart & Nil & Paroxysmal & Nil \\
\hline 24 & 58 & No known heart & $\mathrm{Nil}$ & A.F. & Nil \\
\hline 35 & 52 & No known heart & Nil & S.V.T. & Nil \\
\hline 27 & 14 & $\begin{array}{c}\text { lesion } \\
\text { Operated Fallot's } \\
\text { tetralogy }\end{array}$ & $\begin{array}{c}\text { Intracardiac } \\
\text { procainamide, } \\
\text { propranolol, } \\
\text { and D.C. shock }\end{array}$ & V.F. & $\begin{array}{l}\text { S.R. atter } \\
\text { intracardiac } \\
\text { phenytoin } \\
\text { and D.C. }\end{array}$ \\
\hline 29 & 10 & Operated V.S.D. & Nil & $\begin{array}{l}\text { Multifocal } \\
\text { V.E.S. }\end{array}$ & S.R. \\
\hline 30 & 1 & A.S.D. & Nil & A.F.during & S.R. \\
\hline $\begin{array}{l}31 \\
32\end{array}$ & $\begin{array}{l}3 \\
8\end{array}$ & $\begin{array}{l}\text { A.-V. canal defect } \\
\text { Ebstein's } \\
\text { anomaly }\end{array}$ & $\begin{array}{l}\mathrm{Nil} \\
\mathrm{Nil}\end{array}$ & $\begin{array}{l}\text { s.V.T. } \\
\text { S.V.T. }\end{array}$ & $\begin{array}{l}\text { S.R. } \\
\text { S.R. }\end{array}$ \\
\hline $\begin{array}{l}33 \\
36\end{array}$ & $\begin{array}{r}10 \\
3\end{array}$ & $\begin{array}{l}\text { Operated A.S.D. } \\
\text { Transposition of }\end{array}$ & $\begin{array}{l}\mathrm{Nil} \\
\mathrm{Nil}\end{array}$ & $\begin{array}{l}\text { A.F. } \\
\text { A.Fl. during }\end{array}$ & Nil \\
\hline & weeks & great arteries & & $\begin{array}{l}\text { C.C. and } \\
\text { balloon } \\
\text { septostomy }\end{array}$ & S.R. \\
\hline 28 & 24 & Virus myocarditis & Nil & Ventricular & Nil \\
\hline 7 & 55 & $\begin{array}{l}\text { Ischaemic heart } \\
\text { disease }\end{array}$ & Nil & $\begin{array}{l}\text { A.F. during } \\
\text { C.C. }\end{array}$ & Nil \\
\hline
\end{tabular}

V.S.D.-Ventricular septal defect. A.S.D. = Atrial septal defect.

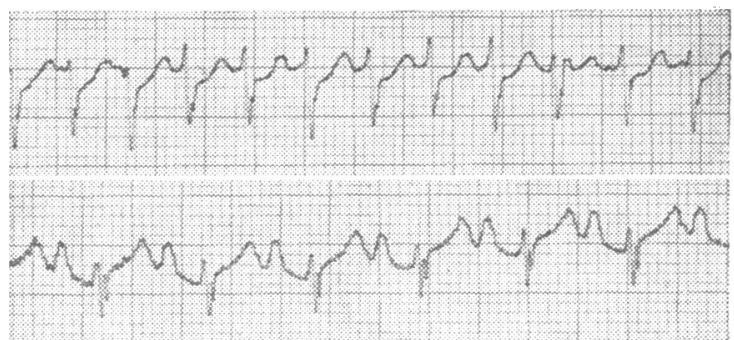

FIG. 4.-Electrocardiogram of a 3-year-old child (Case 31) with supraventricular tachycardia. Bottom tracing shows sinus rhythm following phenytoin sodium.

was one with ventricular bigeminy due to virus myocarditis. Multiple ventricular extrasystoles were satisfactorily suppressed in a patient with a ventricular septal defect in the postoperative period. Also in the postoperative period a child with Fallot's tetralogy developed coarse ventricular fibrillation (Fig. 5), which failed to revert with intracardiac procainamide, propranolol, and repeated D.C. counter shock. External cardiac massage was continued. Finally, after $100 \mathrm{mg}$. of intracardiac phenytoin had been given further D.C. shock restored sinus rhythm.

Oral Therapy.-Two of four patients with multiple ventricular extrasystoles responded completely to oral treatment; in one there was diminution in the frequency of extrasystoles; the other failed with phenytoin but responded to oral propranolol. In a child with Ebstein's anomaly and recurrent supraventricular tachycardia the response to oral phenytoin was very satisfactory, and when the drug was given for a long period as a prophylactic measure it led to significant improvement.

\section{Discussion}

The present evidence suggests that phenytoin is as useful for correcting arrhythmias which are unrelated to digitalis toxicity as it is for those induced by digitalis (Conn, 1965). We found it particularly effective in arrhythmias occurring during the course of acute myocardial infarction and in suppressing abnormal ventricular foci. It is interesting to note that some patients who had developed ventricular arrhythmias after myo- 
cardial infarction and were unresponsive to treatment with lignocaine responded to phenytoin. Weisse et al. (1968) also found it superior to lignocaine in the treatment of abnormal ventricular rhythms following acute myocardial infarction in experimental animals.

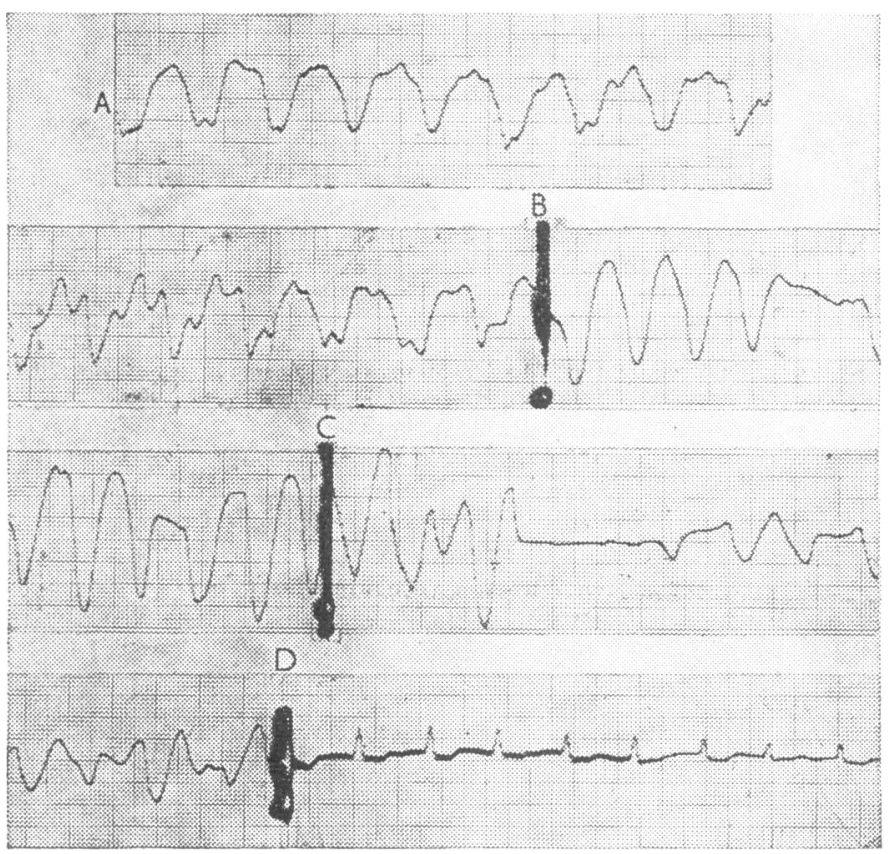

FIG. 5.-Electrocardiogram of a 14-year-old child (Case 27) with Fallor?s tetralogy during the pestoperative period, showing ventricular fibrillation

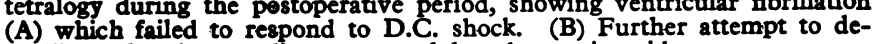
(A) which failed to respond to D.C. shock. (B) Further attempt to deful. (C) Finally, after $100 \mathrm{mg}$. of intracardiac phenytoin had been given further D.C. shock restored sinus rhythm. (D) This strip of E.C.G. shows sinus rhythm following further D.C. shock.

The response to treatment in the second group (Table II) of cases was less impressive; of the 13 cases of supraventricular arrhythmias only four responded. In both groups there were 12 patients with supraventricular arrhythmias who failed to respond to phenytoin, and six of these required cardioversion. This was successful in four, but two required multiple highenergy shocks and it failed completely in two patients despite repeated counter shock. The evidence is insufficient to draw definite conclusions, but it seems that failure with phenytoin occurs in the more resistant cases.

Serious side-effects were rare, but drowsiness was common and two patients complained of transient burning at the site of infusion. Acute hypersensitivity was encountered once and was characterized by urticaria and breathlessness ; it responded to cortisone therapy. A patient who had had acute myocardial infarction and atrial fibrillation developed slow sinus rhythm followed by nodal rhythm which responded transitorily to intravenous atropine but then required transvenous pacing. Sinus slowing sufficient to need artificial pacing has been reported (Bigger et al., 1967), and transient sinus arrest was noted in one patient by Rosen et al. (1967). Unger and Sklaroff (1967) reported two cases of asystole following the intravenous injection of phenytoin.

We have not observed prolongation in atrioventricular or intraventricular conduction time, but Rosen et al. (1967) noted some increase in atrioventricular conduction, notably in cases of atrial flutter that failed to convert. Proctor et al. (1968) compared the effects of phenytoin, a beta-adrenergic agent, and procainamide in 19 dogs with ouabain-induced ventricular tachycardia. At its effective antiarrhythmic dose phenytoin had no significant effect on the $P-R$ interval. The betaadrenergic blocker prolonged atrioventricular conduction and procainamide increased the Q-T interval. Helfant et al. (1967) attempted to determine the electrophysiological effects of phenytoin and compared these with those produced by procainamide. There was transient minimal slowing or no measurable effect on intraventricular conduction with phenytoin. Procainamide increased the intraventricular conduction time with QRS aberration.

Three of our patients had a fall in blood pressure of 10-20 mm. Hg. Transient hypotension has been reported by Rosen et al. (1967). Bigger et al. (1968) found that when phenytoin was given slowly in small repeated doses there was no significant fall in the blood pressure until the accumulated dose exceeded $500 \mathrm{mg}$. We took special precautions to inject the dose of $250 \mathrm{mg}$. slowly over a period of usually more than five minutes, and this might have accounted for the lack of a significant fall in the systemic pressure.

Phenytoin metabolism is decreased in the presence of dicoumarol (Hansen et al., 1966), which is often used as an anticoagulant after myocardial infarction and in such cases is likely to cause toxicity.

The mechanism of action of phenytoin is uncertain. By means of radio-sodium studies Woodbury (1955) demonstrated that phenytoin reduces the sodium content of brain cells and, to a less extent, of heart muscle. Like quinidine it slows conduction between the myocardial fibres. Mixter et al. (1966) suggested that phenytoin acts as a myocardial depressant, and this results in suppression of abnormal rhythm. Helfant et al. (1967) showed that the drug greatly depresses ventricular automaticity in experimental animals.

Lieberson et al. (1967) studied in detail the haemodynamic effect in nine patients. The average heart rate rose from 79 to $87 /$ minute. The mean arterial pressure did not change significantly. There was some fall in $\mathrm{dp} / \mathrm{dt}$ and stroke volume index. The findings showed that phenytoin depresses myocardial function, but the effect may have limited clinical significance, since it was relatively short-lived and the cardiac output was not reduced. In the haemodynamic studies performed by us on two patients (Table III) there was no significant change in the systemic and pulmonary artery pressures or pulse rate after the administration of this drug.

TABLE III.-Effect of Intravenous Phenytoin on Intravascular Pressures in Two Patients

\begin{tabular}{|c|c|c|c|c|c|c|c|}
\hline \multirow{3}{*}{$\begin{array}{l}\text { Case } \\
\text { No. }\end{array}$} & \multirow{3}{*}{ Site } & \multicolumn{6}{|c|}{ Pressures in $\mathrm{mm} . \mathrm{Hg}$} \\
\hline & & \multicolumn{3}{|c|}{ Before Phenytoin } & \multicolumn{3}{|c|}{ After Phenytoin } \\
\hline & & Syst. & Diast. & Mean & Syst. & Diast. & Mean \\
\hline $\begin{array}{r}7 \\
25\end{array}$ & $\begin{array}{ll}\text { Aorta } & \text { Pulmonary artery } \\
\text { Puachial artery } & \text {.. }\end{array}$ & $\begin{array}{r}118 \\
55 \\
84\end{array}$ & $\begin{array}{l}72 \\
18 \\
50\end{array}$ & $\begin{array}{l}85 \\
25 \\
58\end{array}$ & $\begin{array}{r}115 \\
54 \\
85\end{array}$ & $\begin{array}{l}72 \\
20 \\
48\end{array}$ & $\begin{array}{l}80 \\
24 \\
60\end{array}$ \\
\hline
\end{tabular}

Phenytoin is a potent and effective drug in the control of arrhythmias of ventricular and supraventricular origin, and we now use it as the drug of choice for suppressing supraventricular irritable foci. For ventricular arrhythmias we rely initially on well-tried and perhaps less toxic agents such as lignocaine, and reserve phenytoin for patients in whom other measures have failed. Further clinical evaluation is needed before advising that it should be used as the agent of first choice in ventricular arrhythmias.

We wish to thank Dr. C. G. Parsons for his helpful criticism.

\section{REFERENCES}

Bigger, J. T., jun., Steiner, C., and Burris, J. O. (1967). Clinical Research, 15, 196.

Bigger, J. T., jun., Schmidt, D. H., and Kutt, H. (1968). Circulation, 38, 363.

Brenner, O., Davison, P. H., and Evans, D. W. (1964). Lancet, 2, 1184. Conn, R. D. (1965). New England fournal of Medicine, 272, 277. 
Hansen, J. M., Kritensen, M., Skovsted, L., and Christensen, L. K. (1966). Lancet, 2, 265.

Helfant, R. H., Scherlag, B. J., and Damato, A. N. (1967). Circulation, 36, 108.

Leonard, W. A., jun. (1958). Archives of Internal Medicine, 101, 714.

Lieberson, A. D., Schumacher, R. R., Childress, R. H., Boyd, D. L., and Williams, J. F. (1967). Circulation, 36, 692.

Mixter, C. G., Moran, J. M., and Austin, W. G. (1966). American fournal of Cardiology, 17, 332.

Oram, S., and Davies, J. P. H. (1964). Lancet, 1, 1294.
Proctor, J. D., Allen, F. J., and Wasserman, A. J. (1968). Circulation, 38, Suppl. No. 6, p. 158

Rosen, M. R., Lisak, R., and Rubin, I. L. (1967). American foumal of Cardiology, 20, 674 .

Unger, A. H., and Sklaroff, H. J. (1967). Fournal of the American Medical Association, 200, 335.

Weisse, A. B., Moschos, C. B., Passannante, A. J., and Regan, T. J. (1968). Circulation, 38, Suppl. No. 6, p. 205.

Woodbury, D. M. (1955). fournal of Pharmacology and Experimental Therapeutics, 115, 74.

\title{
Platelet Aggregation during Oral Contraception*
}

\author{
L. POLLER, $\dagger$ M.D., M.C.PATH. ; CELIA M. PRIEST, $\ddagger$ M.SC. ; JEAN M. THOMSON,§ F.I.M.L.T.
}

British Medical fournal, 1969, 4, 273-274

\begin{abstract}
Cummary : Platelet aggregation has been found to be significantly accelerated with the coagulation-induced Chandler's tube technique in women taking combined oestrogen-progestin oral contraceptives, though this was less than in the third trimester of pregnancy. Women taking the pure progestogen, chlormadinone acetate, have not shown this change up to the sixth month of study. In contrast the accelerated platelet aggregation resulting from conventional oral contraception became normal one month after changing to the progestogen. There was no change in the platelet aggregation response to adenosine diphosphate (A.D.P.) during oral contraception.
\end{abstract}

\section{Introduction}

Oral contraception with conventional oestrogen-progestin preparations results in rises of clotting factors, including factor $\mathrm{X}$, which is involved in the "intrinsic" clotting system (Poller and Thomson, 1966). When this mechanism is accelerated by physical exertion the platelet aggregation time may also be shortened (Poller et al., 1969c).

We therefore carried out studies in women taking a variety of combined oral contraceptive preparations to see if "longterm" administration produces increased platelet aggregation. During the course of the investigation it became apparent that changes in platelet aggregation were present in these women. It therefore seemed important to study women taking a pure progestogen preparation as soon as this became available for clinical trials, to see if similar changes occurred.

\section{Method of Study}

Platelet aggregation was studied by both the coagulationinduced (Chandler's tube method) and the A.D.P.-induced optical density method.

\section{Chandler's Tube Aggregation}

This was performed in women taking oral contraceptives and in two control groups-that is, 63 normal women and a group of 26 women in the third trimester of pregnancy. Women taking oral contraceptives were divided into four groups:

\footnotetext{
* This work was performed while in receipt of a grant for Thrombosis Research from the Manchester Regional Hospital Board. Supplies of chlormadinone acetate (Normenon) were provided by Syntex
Pharmaceuticals Ltd. t Consultant Haematologist.

$¥$ Research Biochemist.

Chief Research Technician.

Department of Haematology, Withington Hospital, Manchester 20.
}

(1) "High-dose" Group.-Fourteen women taking the listed conventional high-dose oral contraceptive preparations (Gynovlar, 4 ; Norlestrin, 2 ; Ovulen, 2 ; Conovid E, 2 ; Anovlar, 1 ; Lyndiol, 1 ; Minovlar, 1 ; Dista Sequential, 1).

(2) "Low-dose" Group.-Thirty-two women taking the relatively low-dose conventional preparations Norinyl-1 and Ortho-Novin, the latter having twice the hormone content of Norinyl-1.

(3) Progestogen Group A.-Thirty-two women taking a pure progestogen preparation (chlormadinone acetate $0.5 \mathrm{mg}$. daily) and had not taken any oral contraceptive preparation previously.

(4) Progestogen Group B.-Fifteen women who had changed to chlormadinone acetate from combined conventional preparations.

All the women attended at the same time of day (9.3010.30 a.m.) and their blood was collected at mid-cycle. Chandler's tube platelet aggregation studies were performed in the progestogen groups before starting and after one, three, and six months of chlormadinone administration. Women on the relatively low-dose combined preparations, Ortho-Novin and Norinyl-1, were tested at the 18-month stage only. The high-dose group had been taking oral contraceptives for an average of 26 months when they were tested.

\section{A.D.P.-Induced Aggregation}

The A.D.P.-induced optical density method was also used for platelet aggregation studies in a group starting oral contraception for the first time in the progestogen study, in the women taking low-dose conventional preparations, and in the normal controls.

\section{Technique}

The Chandler's tube technique was modified for smaller volumes of blood from the method described previously (Poller et al., 1969a) as follows: the tube of internal diameter $0.6 \mathrm{~cm}$. was rotated at 16 r.p.m. ; $4 \mathrm{ml}$. of $0.9 \%$ sodium chloride and $0.2 \mathrm{ml}$. of $\mathrm{M} / 4$ calcium chloride were used ; $2 \mathrm{ml}$. of plateletrich plasma was added.

The technique for the optical density method was identical to that used previously (Poller et al., 1969a) but slightly modified from O'Brien et al. (1966). The difference between the initial and final optical density readings was measured. The figure was corrected for a platelet count of $400,000 / \mathrm{cu} . \mathrm{mm}$. The concentration of A.D.P. was $5 \times 10^{-6} \mathrm{M}$.

\section{Results}

Results are given in the Table and the Chart; they were analysed for significance at the $5 \%$ level. 